\title{
PENGECUALIAN PERJANJIAN YANG BERKAITAN PATEN DAN LISENSINYA DALAM PENGAWASAN PERSAINGAN USAHA
}

\author{
Hanim Mafulah \\ Universitas Esa Unggul, Jakarta
}

Email Corresponding: hanim.farma@gmail.com

\begin{abstract}
Received: 1 Maret 2020
Abstrak. Penelitian ini bertujuan melakukan kajian tentang bagaimana pengaturan persaingan usaha dan pemberian Lisensi Wajib dalam pelaksanaan Paten untuk mewujudkan keseimbangan antara kepentingan Pemegang Paten/inventor dengan kepentingan masyarakat. Penelitian yang digunakan adalah penelitian hukum normatif deskriptif. Kesimpulannya berdasarkan kasus Perjanjian Supply Agreement 2007 antara PT. Dexa Medica bersama dengan Pfizer Overseas Llc (d/h Pfizer Overseas Inc) atas pelaksanaan Paten zat aktif Amlodipine Besylate dan Pasal 31 huruf $k$ TRIPs Agreement yang diratifikasi dengan Undang-Undang Nomor 7 Tahun 1994 tentang Pengesahan Agreement Establishing The World Trade Organization (Persetujuan Pembentukan Organisasi Perdagangan Dunia) pada Lampiran 25 serta Pasal 14 Peraturan Menteri Hukum dan Hak Asasi Manusia Nomor 30 Tahun 2019 perlu ditindaklanjuti dengan penggunaan Lisensi Wajib Paten yang diberikan untuk memperbaiki praktik persaingan usaha tidak sehat, maka perlu dilakukan peninjauan kembali pengecualian perjanjian yang berkaitan dengan hak atas kekayaan intelektual seperti lisensi dan paten dari Pasal 50 Undang-Undang Nomor 5 Tahun 1999. Sehingga pelaksanaan Paten dan lisensinya yang diduga mengakibatkan praktik monopoli dan atau persaingan usaha tidak sehat dapat menjadi objek pengawasan dan putusan Komisi Pengawas Persaingan Usaha (KPPU).
\end{abstract}

Accepted: 21 Maret 2020

Kata Kunci:

Monopoli;

Paten;

Persaingan Usaha;

Lisensi.

artikel dengan akses terbuka dibawah lisensi CC BY -4.0

\section{PENDAHULUAN}

Sistem perekonomian di Indonesia berbasis demokrasi ekonomi, akan tetapi campur tangan pemerintah sangat diperlukan untuk menciptakan suatu iklim perekonomian negara yang sehat. Negara memiliki peranan penting dalam merumuskan kebijakan yang akan mengarahkan masyarakat agar terjadi persaingan usaha yang sehat tanpa memihak golongan tertentu. Penyebab persaingan usaha tidak sehat diantara para pelaku usaha salah satunya diakibatkan oleh adanya kegiatan monopoli. Suatu kegiatan monopoli adalah kegiatan memusatkan kekuatan ekonomi yang dilakukan oleh satu atau lebih pelaku usaha sehingga dapat menguasai produksi serta pemasaran terhadap 
barang ataupun jasa tertentu yang mengakibatkan persaingan usaha tidak sehat yang merugikan kepentingan masyarakat. ${ }^{1}$ Dengan terciptanya kebijakan yang mengarah pada persaingan usaha yang sehat, maka dibentuklah Undang-Undang Republik Indonesia Nomor 5 Tahun 1999 tentang Larangan Praktek Monopoli dan Persaingan Usaha Tidak Sehat (selanjutnya disebut UU No. 5 Tahun 1999). Berdasarkan Pasal 3 UU No. 5 Tahun 1999 mengatur bahwa tujuan pembentukan undang-undang ini adalah untuk:

a. menjaga kepentingan umum dan meningkatkan efisiensi ekonomi nasional sebagai salah satu upaya untuk meningkatkan kesejahteraan rakyat;

b. mewujudkan iklim usaha yang kondusif melalui pengaturan persaingan usaha yang sehat sehingga menjamin adanya kepastian kesempatan berusaha yang sama bagi pelaku usaha besar, pelaku usaha menengah, dan pelaku usaha kecil;

c. mencegah praktik monopoli dan atau persaingan usaha tidak rehat yang ditimbulkan oleh pelaku usaha; dan

d. terciptanya efektivitas dan efisiensi dalam kegiatan usaha.

Dari ketentuan di atas, terdapat berbagai larangan terhadap tindakan yang dapat menyebabkan terjadinya persaingan usaha yang tidak sehat baik dari aktivitas antar pelaku usaha maupun perjanjian yang melibatkan dua atau lebih pelaku usaha. Undang-undang anti monopoli juga bertujuan untuk mendorong persaingan dalam pasar dengan mencegah penyalahgunaan posisi dominan. ${ }^{2}$

Dalam pelaksanaan aturan hukum yang berlaku, diperlukan lembaga yang diberi kewenangan oleh Negara, dimana berdasarkan Pasal 30 (1) UU No. 5 Tahun 1999 mengatur bahwa "Untuk mengawasi Undang-Undang ini dibentuk Komisi Pengawas Persaingan Usaha yang selanjutnya disebut Komisi". Selanjutnya, berdasarkan Pasal 34 (1) UU No. 5 Tahun 1999 mengatur bahwa "Pembentukan Komisi serta susunan organisasi, tugas, dan fungsinya ditetapkan dengan Keputusan Presiden". Dari ketentuan ini, maka dibentuklah Keputusan Presiden Republik Indonesia Nomor 75 Tahun 1999 sebagaimana telah diubah dengan Peraturan Presiden Republik Indonesia Nomor 80 Tahun 2008 tentang Perubahan Atas Keputusan Presiden Nomor 75 Tahun 1999 tentang Komisi Pengawas Persaingan Usaha.

Adapun salah satu contoh persaingan usaha tidak sehat yang akan diproses oleh Komisi Pengawas Persaingan Usaha (KPPU) ialah perjanjian Kartel. Berdasarkan Pasal 11 UU No. 5 Tahun 1999 mengatur bahwa:

"Pelaku usaha dilarang membuat perjanjian, dengan pelaku usaha pesaingnya, yang bermaksud untuk mempengaruhi harga dengan mengatur produksi dan atau pemasaran suatu barang dan atau jasa, yang dapat mengakibatkan terjadinya praktik monopoli dan atau persaingan usaha tidak sehat."

\footnotetext{
${ }^{1}$ Ida Bagus Kade Benol Permadi \& A. A Ketut Sukranatha. (2015). Konsep Rule of Reason untuk mengetahui Praktek Monopoli. Kertha Semaya: Journal Ilmu Hukum, Universitas Udayana, 3(3), hlm. 1.

${ }^{2}$ Mamta Rani Jha. (2018, 16 April). The Interplay between Patents and Anti-Competitive Practices. Dalam IAM.
} 
Dari ketetapan di atas, dapat dimaksudkan bahwa perjanjian kartel dapat menimbulkan persaingan usaha tidak sehat karena kedua pelaku usaha tersebut bekerjasama untuk mengatur produksi dan atau pemasaran barang dan jasa dan berujung pada perjanjian penetapan harga (price fixing agreement). Perjanjian penetapan harga ini dimaksudkan untuk menghasilkan laba yang sebesar-besarnya. Dengan demikian, perjanjian penetapan harga ini akan meniadakan persaingan dari faktor harga terhadap produk yang dijual atau dipasarkan oleh pelaku usaha tersebut. Di sisi lain, praktik kartel dengan perjanjian penetapan harga ini membuat pelaku usaha memiliki kekuatan dalam menguasai pasar dan menentukan harga secara sepihak yang tidak wajar sehingga mengakibatkan kerugian konsumen karena konsumen terpaksa membayar harga yang mahal. Dengan adanya tindakan kartel semacam ini, konsumen terpaksa harus menerima barang dan harga yang ditawarkan oleh pelaku usaha dan tidak memiliki alternatif untuk memiliki produk dari produsen lain. ${ }^{3}$ Kartel dalam bisnis adalah salah satu contoh kejahatan korporasi dan kejahatan ekonomi yang didalamnya terdapat kolusi antara pesaing untuk menetapkan harga, pembagian pasar, ataupun pembagian tender. ${ }^{4}$

Pembuktian terjadinya pelanggaran didasarkan pada hasil analisis dan pembuktian bahwa semua unsur dari tiap Pasal telah terpenuhi. Akan tetapi, praktik kartel biasanya dilakukan secara tertutup sehingga pembuktiannya sulit. KPPU akan sulit dalam menemukan perjanjian tertulis antar pelaku usaha maupun dokumen-dokumen lain yang dibutuhkan yang berisi harga, wilayah pemasaran, maupun produksi barang/jasa antar pelaku usaha. Dalam perkembangannya, dibutuhkan alat bukti tidak langsung yang disebut bukti tidak langsung (indirect evidence). ${ }^{5}$

Sebagai contoh kasus terjadinya kartel adalah Putusan KPPU Nomor 17/KPPU-I/2010 dimana pada awalnya, terjadi sengketa antara Pfizer Inc. sebagai pemilik kekayaan intelektual khususnya Paten zat aktif Amlodipine Besylate ${ }^{6}$ (masa perlindungan Paten berakhir pada tanggal 3 April 2007) dengan PT. Dexa Medica. Sengketa tersebut diselesaikan dengan Supply Agreement dengan Pfizer Overseas LLC untuk pemasokan bahan baku. PT. Pfizer Indonesia juga mendapatkan bahan baku dari pemasok yang sama. PT. Pfizer Indonesia memproduksi obat anti hipertensi yang berisi kandungan zat aktif Amlodipine Besylate dengan merek dagang "Norvask". Sedangkan PT. Dexa Medica membuat obat dengan bahan baku dan manfaat yang sama dengan merek dagang "Tensivask". Harga Norvask kemasan 5mg maupun kemasan 10mg, harganya

\footnotetext{
${ }^{3}$ Andi Fahmi Lubis \& Ningrum Natasya Sirait (Eds.). (2009). Hukum Persaingan Usaha: Antara Teks dan Konteks. Jakarta: Gesellschaft für Technische Zusammenarbeit (GTZ), hlm. 90.

${ }^{4}$ J. D. Jaspers. (2017). Managing Cartels: How Cartel Participants Create Stability in the Absence of Law. European Journal on Criminal Policy and Research, Springer Nature, 23, hlm. 319 - 335.

${ }^{5}$ Udin Silalahi \& Isabella Cynthia Edgina. (2017). Pembuktian Perkara Kartel di Indonesia dengan Menggunakan Bukti Tidak Langsung (Indirect Evidence). Jurnal Yudisial, Komisi Yudisial Republik Indonesia, 10(3), hlm. 311 - 330.

${ }^{6}$ Senyawa Amlodipine Besylate merupakan obat kardiovaskular, hipertensi dan angina. Amlodipin memiliki sifat antioksidan dan memiliki kemampuan antioksidan dan memiliki kemampuan untuk meningkatkan produksi nitrat oksida (NO), suatu vasodilator penting yang dapat menurunkan tekanan darah. Lihat Editorial. (2019, 24 April). Amlodipine Besylate. Dalam DrugBank.
} 
terus mengalami kenaikan secara sistematis selama periode tahun 2000 sampai awal 2010. Sedangkan harga Tensivask baik yang kemasan $5 \mathrm{mg}$ dan $10 \mathrm{mg}$ mengalami kenaikan 7x kali (5mg) dan 3x (10mg) selama periode tahun 2000 sampai awal 2010.

Berdasarkan survei yang dilakukan oleh DepKes bekerjasama dengan WHO pada tahun 2004 - 2005, diperoleh nilai MPR (Median Medicines Price Ratios) Amlodipine $5 \mathrm{mg}$ tab/cap di Indonesia, yaitu untuk Innovator Brand (Norvask) sebesar 51,13 kali lebih mahal dari harga acuan internasional untuk Rumah Sakit Umum, sementara untuk Rumah Sakit Swasta, harga jual Norvask di Indonesia 53,26 kali lebih mahal dari harga acuan international. Sementara nilai MPR untuk Tensivask di Rumah Sakit Swasta adalah 49,43 kali lebih mahal daripada harga acuan internasional, sementara nilai MPR untuk Tensivask di Rumah Sakit Umum 45,85 kali lebih mahal dari harga acuan internasional.

Dari penjelasan kasus di atas, KPPU memutuskan bahwa kedua perusahaan tersebut melanggar Pasal 5 (tentang Penetapan Harga), Pasal 11 (tentang Kartel) dan Pasal 16 (tentang Perjanjian dengan Pihak Luar Negeri) UU No. 5 Tahun 1999 yang mengakibatkan persaingan usaha tidak sehat.

Jika dilihat lebih dalam, fakta-fakta dalam contoh kasus ini membuktikan bahwa praktik monopoli yang mengakibatkan persaingan usaha tidak sehat terjadi sepenuhnya selama masa perlindungan Paten sehingga kepentingan masyarakat dirugikan terkait dengan harga obat yang mahal dan konsumen tidak memiliki alternatif lain untuk membelinya.

Untuk itu, diperlukan kajian mengenai bagaimana pengaturan persaingan usaha dan pemberian Lisensi Wajib dalam pelaksanaan Paten untuk mewujudkan keseimbangan antara kepentingan Pemegang Paten/inventor dengan kepentingan masyarakat.

\section{METODE}

Jenis penelitian ini adalah penelitian hukum normatif yang juga disebut dengan penelitian hukum teoritis atau dogmatik karena tidak mengkaji pelaksanaan atau implementasi hukum. ${ }^{7}$ Menurut Soerjono Soekanto penelitian hukum normatif adalah penelitian hukum yang dilakukan dengan cara meneliti bahan pustaka atau data sekunder. ${ }^{8}$ Tipe penelitian yang digunakan adalah deskriptif, dimana bertujuan untuk mendapatkan pemaparan (deskripsi) secara utuh, terperinci, jelas, dan sistematis tentang beberapa aspek yang diteliti pada undang-undang, dan/atau peraturan pelaksanaannya atau naskah perjanjian ataupun objek kajian lainnya. ${ }^{9}$ Pengumpulan data dilakukan dengan melakukan kegiatan studi pustaka, studi dokumen, studi catatan dan studi catatan hukum. Penelitian ini bersifat analisis deskriptif dimana melakukan

\footnotetext{
${ }^{7}$ Nurul Qamar, et al. (2017). Metode Penelitian Hukum (Legal Research Methods). Makassar: CV. Social Politic Genius (SIGn), hlm. 49.

${ }^{8}$ Soerjono Soekanto \& Sri Mamudji. (2015). Penelitian Hukum Normatif: Suatu Tinjauan Singkat. Jakarta: PT. Raja Grafindo Persada, hlm. 15.

${ }^{9}$ Ibid., hlm. 115.
} 
interpretasi bahan hukum yang terbatas pada masalah penelitian yang diteliti. ${ }^{10}$ Adapun bahan yang akan dianalisis adalah peraturan tentang pengaturan larangan praktek monopoli dan persaingan usaha tidak sehat, pengaturan tentang Paten, pengaturan Tata Cara Pemberian Lisensi Wajib Paten serta perjanjian internasional yang telah diratifikasi, yaitu Keputusan Presiden Republik Indonesia Nomor 24 Tahun 1979 sebagaimana telah diubah dengan Keputusan Presiden Republik Indonesia Nomor 15 Tahun 1997 tentang Perubahan Keputusan Presiden Nomor 24 Tahun 1979 tentang Pengesahan Paris Convention for the Protection of Industrial Property dan Convention Establishing the World Intellectual Property Organization (selanjutnya disebut Keppres No. 15 Tahun 1997), Undang-Undang Republik Indonesia Nomor 7 Tahun 1994 tentang Pengesahan Agreement Establishing the World Trade Organization (Persetujuan Pembentukan Organisasi Perdagangan Dunia) (selanjutnya disebut UU No. 7 Tahun 1994), Perjanjian TRIPs dan Annexnya. Lebih lanjut, penelitian ini akan berusaha memperoleh hasil yang komprehensif dan mendalam untuk dapat ditarik kesimpulan yang selaras dengan rumusan masalah.

\section{PEMBAHASAN}

Hukum persaingan usaha merupakan hukum yang mengatur tentang interaksi perusahaan atau pelaku usaha di pasar, sementara tingkah laku perusahaan ketika berinteraksidilandasiatas motif-motifekonomi. ${ }^{11}$ Secarayuridis, pengertian persaingan usaha selalu dikaitkan dengan persaingan dalam sisi ekonomi yang berbasis pada pasar, dimana pelaku usaha baik perusahaan maupun penjual secara bebas berupaya untuk menarik konsumen guna mencapai tujuan usaha atau perusahaan tertentu yang didirikan. ${ }^{12}$ Tujuan persaingan usaha adalah bagaimana menguasai pasar dan menjadi pasar. Konsep hukum persaingan usaha adalah menjaga persaingan usaha yang sehat tetap terjadi di pasar yang bersangkutan dan mendorong pelaku usaha menjadi pelaku usaha yang mempunyai posisi dominan (menjadi unggul) melalui persaingan usaha yang sehat dan efektif.

Kebijakan dalam hukum persaingan usaha bertujuan untuk mewujudkan peningkatan kesejahteraan konsumen dengan cara mengeliminasi hal-hal yang dapat menghambat fungsi pasar secara efisien. Salah satu caranya adalah dengan pencegahan terhadap tindakan kartel yang ditujukan pada penetapan harga, membatasi tingkat persaingan dengan para kompetitornya dan dengan mencegah perusahaan dengan kekuatan pasar untuk menyalahgunakan posisi dominan yang dimilikinya.

Tujuan kebijakan dalam hukum persaingan usaha secara umum terkait dengan upaya untuk mendorong efisiensi jangka pendek dengan mengupayakan agar harga pasar

\footnotetext{
${ }^{10}$ Jonaedi Efendi \& Johnny Ibrahim. (2016). Metode Penelitian Hukum: Normatif dan Empiris. Jakarta: Kencana Prenada Media Group.

${ }^{11}$ Indah Nirmalasari Parinduri. (2013). Pengaruh Pasar Modern terhadap Pasar Tradisional Ditinjau dari Perspektif Teori Hukum. Dalam Jendela Informasi Hukum: Bidang Perdagangan, diedit oleh Sutowibowo Setiadhy, Simon Tumanggor, \& Mu'min. Jakarta: Biro Hukum, Kementerian Perdagangan, hlm 13.

${ }^{12}$ Andi Fahmi Lubis \& Ningrum Natasya Sirait (Eds.). (2009). Op. Cit ., hlm. 21.
} 
terdorong ka arah biaya marjinal sehingga akan memaksimalkan hasil sumber daya masyarakat. Hal ini mungkin akan tampak kontradiktif dengan prinsip hak eksklusif yang ada pada hak kekayaan intelektual. Akan tetapi, hal ini dapat diperhitungkan dan dapat dipertimbangkan jika kesejahteraan konsumen dapat diwujudkan dalam jangka Panjang. Kesejahteraan konsumen dalam jangka panjang akan tergantung pada komersialisasi produk-produk baru hasil inovasi dan proses-proses yang dapat meningkatkan kesejahteraan dengan cara meningkatkan kualitas dari produk-produk yang dipasarkan maupun cara-cara produksi yang efisien.

UU No. 5 Tahun 1999 tidak melarang pelaku usaha menjadi perusahaan besar. UU No. 5 Tahun 1999 justru mendorong pelaku usaha untuk dapat bersaing pada pasar yang bersangkutan. Persaingan inilah yang memacu pelaku usaha untuk melakukan efisiensi dan inovasi-inovasi untuk menghasilkan produk yang lebih berkualitas dan harga yang kompetitif dibandingkan dengan kualitas produk dan harga jual dari pesaingnya. Persainganlah yang mendorong pelaku usaha menjadi pelaku usaha yang dominan. ${ }^{13}$

Secara yuridis konstitusional, kebijakan dan pengaturan hukum persaingan usaha didasarkan pada ketentuan dalam Pasal 33 Undang-Undang Dasar Negara Republik Indonesia Tahun 1945 (selanjutnya disebutUUD NRI Tahun 1945), yang mengamanatkan tidak adanya monopoli yang dapat merugikan masyarakat dan persaingan usaha tidak sehat. ${ }^{14}$ Dalam Pasal 33 UUD NRI Tahun 1945 secara implisit mengungkapkan tentang demokrasi ekonomi yang diwujudkan oleh seluruh rakyat demi kepentingan seluruh rakyat, serta harus mengabdi kepada kesejahteraan seluruh rakyat Indonesia.

Selaras dengan penjelasan di atas, berdasarkan Pasal 2 UU No. 5 Tahun 1999 mengatur bahwa: "Pelaku usaha di Indonesia dalam menjalankan kegiatan usahanya berasaskan demokrasi ekonomi dengan memperhatikan keseimbangan antara kepentingan pelaku usaha dan kepentingan umum".

Selanjutnya, berdasarkan Pasal 3 UU No. 5 Tahun 1999 mengatur bahwa tujuan pembentukan undang-undang ini adalah untuk:

a. menjaga kepentingan umum dan meningkatkan efisiensi ekonomi nasional sebagai salah satu upaya untuk meningkatkan kesejahteraan rakyat;

b. mewujudkan iklim usaha yang kondusif melalui pengaturan persaingan usaha yang sehat sehingga menjamin adanya kepastian kesempatan berusaha yang sama bagi pelaku usaha besar, pelaku usaha menengah, dan pelaku usaha kecil;

c. mencegah praktik monopoli dan atau persaingan usaha tidak sehat yang ditimbulkan oleh pelaku usaha; dan

d. terciptanya efektivitas dan efisiensi dalam kegiatan usaha.

Pada standar dan praktik paten internasional, telah diratifikasi Konvensi Paris untuk Perlindungan Properti Industri terakhir tanggal 7 Mei 1997 dengan Keppres No. 15

\footnotetext{
${ }^{13}$ Editorial. (2018). Laporan Kinerja: Komisi Pengawas Persaingan Usaha 2017. Jakarta: Komisi Pengawas Persaingan Usaha (KPPU) RI, hlm. 4.

${ }^{14}$ Rachmadi Usman. (2013). Hukum Persaingan Usaha di Indonesia. Jakarta: Sinar Grafika., hlm. 62.
} 
Tahun 1997. Agreement on Trade-Related Aspects of Intellectual Property Rights (TRIPs) atau Perjanjian Aspek-aspek dagang yang terkait dengan Hak Atas Kekayaan Intelektual yang telah diratifikasi tanggal 2 Nopember 1994 dengan UU No. 7 Tahun 1994.

Kedua perjanjian tersebut menjadi dasar undang-undang paten di sebagian besar negara, yang saling mengakui, mempengaruhi dan mendasari antara undang-undang paten dan persaingan usaha. Bahkan menawarkan panduan tentang bagaimana tumpang tindih ketentuan dapat ditangani antara undang-undang paten dan persaingan usaha. Secara khusus, Pasal 5A ayat (2) Paris Convention for the Protection of Industrial Property mengatur bahwa:

"Each country of the Union shall have the right to take legislative measures providing for the grant of compulsory licenses to prevent the abuses which might result from the exercise of the exclusive rights conferred by the patent, for example, failure to work."

Dari ketetapan Konvensi Paris di atas, setiap negara dapat mempertimbangkan pemberian lisensi wajib untuk mencegah penyalahgunaan yang mungkin timbul dari pemberian hak paten monopolistik. Demikian pula berdasarkan Pasal 8 angka 2 TRIPs Agreement mengatur bahwa:

"Appropriate measures, provided that they are consistent with the provisions of this Agreement, may be needed to prevent the abuse of intellectual property rights by right holders or the resort to practices which unreasonably restrain trade or adversely affect the international transfer of technology"

Selanjutnya, berdasarkan Pasal 31 huruf k TRIPs Agreement mengatur bahwa:

"Members are not obliged to apply the conditions set forth in subparagraphs (b) and (f) where such use is permitted to remedy a practice determined after judicial or administrative process to be anti-competitive. The need to correct anti-competitive practices may be taken into account in determining the amount of remuneration in such cases. Competent authorities shall have the authority to refuse termination of authorization if and when the conditions which led to such authorization are likely to recur."

Dari TRIPs Agreement di atas, diatur bahwa untuk memperbaiki praktikyang ditentukan setelah proses administratif melalui keputusan lembaga terkait atau proses peradilan melalui putusan pengadilan. Adapun pelaksanaan Paten tersebut dinyatakan sebagai tindakan monopoli atau persaingan usaha tidak sehat dapat diberikan Lisensi Wajib Paten. Syarat adanya upaya yang wajar untuk mengajukan lisensi kepada pemegang paten dalam jangka waktu tertentu dan harus mengutamakan pasokan kebutuhan pasar dalam negeri juga tidak wajib diterapkan. Lisensi Wajib Paten adalah ketika pemerintah mengizinkan orang lain untuk menghasilkan produk atau proses yang dilindungi paten tanpa persetujuan dari pemegang paten atau untuk menggunakan invensi yang dilindungi paten itu oleh pemerintah. ${ }^{15}$

${ }^{15}$ Editorial. (2019, 27 Desember). Compulsory Licensing of Pharmaceuticals and TRIPS. Dalam World Trade Organization. 
Lebih lanjut, berdasarkan Pasal 40 angka 1 dan 2 TRIPs Agreement mengatur bahwa:

1. Members agree that some licensing practices or conditions pertaining to intellectual property rights which restrain competition may have adverse effects on trade and may impede the transfer and dissemination of technology.

2. Nothing in this Agreement shall prevent Members from specifying in their legislation licensing practices or conditions that may in particular cases constitute an abuse of intellectual property rights having an adverse effect on competition in the relevant market. As provided above, a Member may adopt, consistently with the other provisions of this Agreement, appropriate measures to prevent or control such practices, which may include for example exclusive grantback conditions, conditions preventing challenges to validity and coercive package licensing, in the light of the relevant laws and regulations of that Member.

Dari TRIPs Agreement di atas, setiap negara-negara anggota WTO memungkinkan untuk mengambil langkah-langkah yang tepat untuk mencegah penyalahgunaan hak paten melalui praktik-praktik yang secara tidak wajar menahan perdagangan atau berdampak buruk pada transfer teknologi internasional. Perjanjian internasional ini mengakui perlunya mencapai keseimbangan antara hak monopolistik dan permainan yang adil, meskipun kebijaksanaan penuh telah diberikan pada negara-negara anggota WTO untuk mengaturnya dalam undang-undang mereka masing-masing. ${ }^{16}$

Menyikapi TRIPs Agreement, maka dibentuklah Undang-Undang Republik Indonesia Nomor 13 Tahun 2016 tentang Paten (selanjutnya disebut UU No. 13 Tahun 2016) dan Peraturan Menteri Hukum dan Hak Asasi Manusia Republik Indonesia Nomor 30 Tahun 2019 tentang Tata Cara Pemberian Lisensi-Wajib Paten (selanjutnya disebut Permenkumham No. 30 Tahun 2019).

Lisensi Wajib Paten dalam menangani praktik persaingan usaha tidak sehat juga dapat diberikan sejauh yang dimaksudkan di bidang teknologi semi-konduktor, dimana berdasarkan Pasal 100 huruf b UU No. 13 Tahun 2016 mengatur bahwa:

"Melaksanakan tindakan yang ditentukan berdasarkan putusan pengadilan atau keputusan lembaga terkait yang menyatakan bahwa pelaksanaan paten dimaksud merupakan tindakan monopoli atau persaingan usaha tidak sehat."

Berdasarkan Pasal 5 ayat (2) huruf b Permenkumham No. 30 Tahun 2019 mengatur bahwa "dalam menangani praktik yang berdasarkan proses hukum atau administratif dinyatakan sebagai persaingan usaha tidak sehat".

Selanjutnya, Berdasarkan Pasal 14 Permenkumham No. 30 Tahun 2019 mengatur bahwa "Ketentuan ... ini tidak harus dilakukan apabila penggunaan tersebut diijinkan untuk mengatasi praktik yang ditetapkan melalui proses peradilan atau administratif sebagai persaingan curang".

${ }^{16}$ Mamta Rani Jha. (2018, 16 April). Loc. Cit. 
Di sisi lain, terdapat pengecualian dalam larangan yang berdasarkan Pasal 50 huruf b UU No. 5 Tahun 1999 mengatur bahwa yang dikecualikan dari ketentuan undangundang ini adalah:

"perjanjian yang berkaitan dengan hak atas kekayaan intelektual seperti lisensi, paten, merek dagang, hak cipta, desain produk industri, rangkaian elektronik terpadu. dan rahasia dagang, serta perjanjian yang berkaitan dengan waralaba."

Padahal jika merujuk pada kasus perjanjian yang berkaitan paten dan lisensi zat aktif Amlodipine Besylate antara PT. Dexa Medica dan kelompok usaha Pfizer berdasarkan putusan Komisi Pengawas Persaingan Usaha (KPPU) nomor 17/KPPU-I/2010 tanggal 27 September 2010, yang menyatakan bahwa:

1. Fakta bahwa setelah masa paten Amlodipine besylate berakhir dibuat perpanjangan Perjanjian Supply Agreement 2007 antara PT. Dexa Medica bersama dengan Pfizer Overseas Llc (d/h Pfizer Overseas Inc) selaku anak perusahaan Pfizer Inc yang berkedudukan di luar negeri, dan Posisi Dominan PT. Pfizer Indonesia secara tidak langsung mempengaruhi peresepan obat hipertensi melalui program HCCCP melibatkan peran dokter, telah mengakibatkan terjadinya praktek monopoli dan atau persaingan usaha tidak sehat.

2. Kegiatan kelompok usaha Pfizer yang terdiri dari Terlapor I/PT. Pfizer Indonesia, Terlapor III/Pfizer Inc., Terlapor IV/Pfizer Overseas LLC, Terlapor V/Pfizer Global Trading dan VI/PT. Pfizer Corporation Panama serta Terlapor II/PT. Dexa Medica dalam pemasokan bahan baku zat aktif Amlodipine Besylate untuk obat hipertensi merek Norvask dan Tensivask termasuk indikasi Kartel dan Posisi Dominan yang melanggar Pasal 5, Pasal 11, Pasal 16, Pasal 25 Undang-undang nomor 5 tahun 1999.

Praktik monopoli dan persaingan usaha tidak sehat dalam kasus tersebut, dapat diduga telah terjadi sebelum berakhirnya masa paten Amlodipine Besylate sejak 3 April 1987 dan berakhir 3 April 2007 dengan pemegang paten Pfizer Overseas LLC. Karena Putusan KPPU tersebut mengungkapkan fakta bahwa dalam masa paten zat aktif Amlodipine Besylate telah menjadi bahan baku obat Norvask. Tetapi PT. Dexa Medica justru memproduksi obat Tensivask yang mengandung Amlodipine Besylate dengan izin edar Depkes RI dan BPOM tanggal 12 Desember 1994. Sehingga latar belakang adanya Supply Agreement tersebut antara Pfizer Overseas dan PT. Dexa Medica berkaitan adanya pelanggaran paten yang dilakukan oleh PT. Dexa Medica kepada Pfizer Inc. Perjanjian Supply Agreement dimulai sejak tanggal 27 Februari 1997 dan perpanjangan Perjanjian Supply Agreement 2007 dimana jangka waktu kontrak diperpanjang tiap tahun sampai saat ini.

Berdasarkan perjanjian Supply Agreement sejak tahun 1997 antara Kelompok Usaha Pfizer dengan PT. Dexa Medica menetapkan harga obat Anti Hipertensi dengan Zat Aktif Amlodipine Besylate. Kesepakatan tentang pencantuman kalimat dalam kemasan produk dimana berdasarkan Pasal 5 Supply Agreement 2007 mengatur bahwa: 
"Pembeli dapat, ketika Perjanjian ini masih berlaku, menuliskan kalimat sebagai berikut pada kemasan Produk yang disiapkan oleh Pembeli dan dipasarkan dalam Wilayah; Diproduksi dengan menggunakan material aktif dari Pfizer."

Kesepakatan tentang pemutusan perjanjian akibat tindakan kelebihan produksi oleh Pembeli yang tidak sesuai dengan bahan baku dimana berdasarkan Pasal 13 huruf c angka iv Supply Agreement 2007 mengatur bahwa:

"Jika pemasok melihat bahwa jumlah kuantitas dari produk yang dijual di wilayah Indonesia berlebih dan tidak sesuai dengan kuantitas dari produk yang dapat diproduksi oleh pembeli dari bahan baku yang dibeli dari pemasok."

Kesepakatan tentang Kewajiban memberikan informasi kepada pihak ketiga yaitu Pfizer Indonesia dimana berdasarkan Pasal 18 Supply Agreement 2007 mengatur bahwa:

"Semua pemberitahuan, persetujuan dan komunikasi yang terkait dengan perjanjian ini harus dalam bentuk tertulis dan harus dikirimkan melalui facsimile, pengiriman langsung atau lewat surat sesuai dengan alamat para pihak dalam perjanjian ini dan copy-nya kepada Pfizer Indonesia dengan ketentuan bahwa semua informasi atau komunikasi harus sampai ke pihak pfizer dalam jangka waktu yang ditentukan dalam perjanjian."

Pasal 5 jo. Pasal 13 huruf c angka iv jo. Pasal 18 Supply Agreement 2007 dapat diduga telah melanggar Pasal 5 ayat (1) UU No. 5 Tahun 1999 mengatur bahwa:

"Pelaku usaha dilarang membuat perjanjian dengan pelaku usaha pesaingnya untuk menetapkan harga atas suatu barang dan atau jasa yang harus dibayar oleh konsumen atau pelanggan pada pasar bersangkutan yang sama."

Fakta lainnya, bahwa Kelompok Usaha Pfizer dengan PT. Dexa Medica berdasarkan Perjanjian Supply Agreement sejak tahun 1997 secara bersama melakukan pengaturan produksi dan pengaturan pemasaran obat Anti Hipertensi dengan Zat Aktif Amlodipine Besylate. Kelompok Usaha Pfizer dengan PT. Dexa Medica telah bersepakat berdasarkan Pasal 9.1 angka (v) Supply Agreement 2007 mengatur bahwa:

"Secara berkala berdasarkan bentukyang ditetapkan oleh principal, distributor berjanji memberikan informasi pasar, perkembangan di wilayah yang diperjanjikan, statistic perdagangan, informasi tentang kegiatan pesaing, dan informasi lain yang di minta oleh principal agar produk dapat dipromosikan dengan mendapatkan keuntungan yang terbaik sebagai promosi yang efektif di wilayah produk tersebut yang menjadi perhatian penting bagi kedua belah pihak dalam perjanjian."

Dari ketetapan Supply Agreement di atas dapat dikualifikasikan sebagai perbuatan Kartel karena melanggar Pasal 11 UU No. 5 Tahun 1999 yang mengatur bahwa:

"Pelaku usaha dilarang membuat perjanjian, dengan pelaku usaha pesaingnya, yang bermaksud untuk mempengaruhi harga dengan mengatur produksi dan atau pemasaran suatu barang dan atau jasa, yang dapat mengakibatkan terjadinya praktik monopoli dan atau persaingan usaha tidak sehat." 
Selanjutnya, PT. Dexa Medica bersama Kelompok Usaha Pfizer diduga melakukan perjanjian dengan pihak lain di luar negeri yang berakibat terjadinya praktik monopoli dan persaingan usaha tidak sehat. Hal ini jelas melanggar Pasal 16 UU No. 5 Tahun 1999 yang mengatur bahwa "Pelaku usaha dilarang membuat perjanjian dengan pihak lain di luar negeri yang memuat ketentuan yang dapat mengakibatkan terjadinya praktik monopoli dan atau persaingan usaha tidak sehat".

Pihak lain di luar negeri adalah Pfizer Overseas LLC (d/h. Pfizer Overseas Inc) dengan alamat 235 East 42nd Street New York NY 117, USA; Alamat alternatif Pottery Road Dun Laoire Dublin, Ireland Phone: 35312049100 Fax: 35312856108 merupakan anak perusahaan Pfizer Inc dengan alamat 235 East 42nd Street New York NY 117, USA. Pfizer Overseas LLC bertindak sebagai pihak dalam perjanjian Supply Agreement dengan PT. Dexa Medica untuk pemasokan bahan baku zat aktif Amlodipine Besylate untuk obat hipertensi dengan merek Tensivask diproduksi PT. Dexa Medica dan merek Norvask diproduksi PT. Pfizer Indonesia.

Perjanjian Supply Agreement 2007 antara PT. Dexa Medica bersama dengan Pfizer Overseas Llc ( $\mathrm{d} / \mathrm{h}$ Pfizer Overseas Inc) telah mengakibatkan terjadinya praktik monopoli dan atau persaingan usaha tidak sehat, karena tidak terjadi persaingan antara produk merek Norvask dari PT. Pfizer Indonesia dengan produk merek Tensivask dari PT. Dexa Medica meskipun bahan baku yang sama zat aktif Amlodipine Besylate, berdasarkan hasil analisa data pengawasan KPPU terhadap pangsa pasar obat anti hipertensi tersebut menunjukkan bahwa :

a. terdapat pola paralel dalam fluktuasi maupun ko integrasi terkait dengan volume penjualan produk Norvask dan Tensivask di Pasar meningkat secara linier (relatif stabil), dimana besaran penyesuaian atau kenaikan harga relatif identik antara 3-6 persen karena berpeluang mendapat informasi harga pesaing secara sistematis melalui distributor dan IMS report;

b. harga produk Norvask dan Tensivask dapat dikatakan excessive berdasarkan rasio Medicine Price Ratio (MPR) kedua merek tersebut terhadap harga acuan internasional, perbandingan data MPR sepanjang 2004 - 2009, dapat diperoleh nilai rata-rata MPR untuk Norvask adalah 14,6 kali di atas harga acuan internasional dan Tensivask sebesar 13,60 kali di atas harga acuan internasional, padahal batasan rasio MPR yang dikategorikan excessive menurut WHO adalah di atas 2,5 kali dari harga acuan internasional;

c. harga produk Norvask dan Tensivask relatif lebih mahal dibanding harga rata-rata obat generik dalam pasar bersangkutan yang sama dengan mempertimbangkan perbedaan harga Norvask dan Tensivask bagi konsumen non-ASKES dengan Norvask dan Tensivask untuk peserta ASKES yang signifikan dimana salah satu penyebabnya diakibatkan oleh faktor biaya pemasaran. 
Selain itu, hasil analisa data pengawasan KPPU terhadap pangsa pasar obat Norvask periode 2000 - 2007 menunjukkan telah mencapai di atas 50 persen. Kondisi tersebut memenuhi kriteria Posisi Dominan menurut Pasal 25 ayat (2) UU No. 5 Tahun 1999. Posisi Dominan Pfizer untuk produk Norvask menjadi lebih kuat karena adanya hak paten yang berlaku sejak 3 April 1987 dan berakhir 3 April 2007. Hak paten tersebut mengakibatkan tidak ada pelaku usaha pesaing yang dapat menawarkan produk sejenis, selain PT. Dexa Medica dalam periode yang bersangkutan.

Posisi Dominan Kelompok Usaha Pfizer tersebut menurut KPPU telah disalahgunakan untuk mempengaruhi dokter dan/atau apotek agar hanya meresepkan obat dengan merek Norvask melalui Program HCCP. Peran dokter dalam peresepan obat sangat penting, karena pihak apotik tidak dapat merubah resep yang sudah dituliskan dokter. Pihak dokter yang memberikan kartu anggota HCCP kepada pasien, dimana pihak apotik hanya melaksanakan fungsi input data pasien melalui mesin EDC yang disediakan Pfizer Indonesia. Penyalahgunaan Posisi Dominan ini melanggar Pasal 25 ayat (1) huruf a UU No. 5 Tahun 1999 yang mengatur bahwa:

"Pelaku usaha dilarang menggunakan posisi dominan baik secara langsung maupun tidak langsung untuk menetapkan syarat-syarat perdagangan dengan tujuan untuk mencegah dan atau menghalangi konsumen memperoleh barang dan atau jasa yang bersaing, baik dari segi harga maupun kualitas."

Akan tetapi, berdasarkan Pasal 50 huruf b UU No. 5 Tahun 1999 dalam pemeriksaan KPPU oleh pihak-pihak Terlapor dijadikan dasar alasan pengecualian dari ketentuan UU No. 5 Tahun 1999 sebagaimana telah disebutkan sebelumnya di atas. Karena perpanjangan perjanjian Supply Agreement dianggap perjanjian yang berkaitan dengan hak atas kekayaan intelektual seperti lisensi, paten. ${ }^{17}$ Berdasarkan Pasal 1 angka 1 UU No. 13 Tahun 2016 jo. Pasal 1 angka 1 Permenkumham No. 30 Tahun 2019 mengartikan bahwa:

"Paten adalah hak eksklusif yang diberikan oleh negara kepada inventor atas hasil invensinya di bidang teknologi untukjangka waktu tertentu melaksanakan sendiri invensi tersebut atau memberikan persetujuan kepada pihak lain untuk melaksanakannya."

Adapun berdasarkan Penjelasan Pasal 19 ayat (1) UU No. 13 Tahun 2016, bahwa:

"Yang dimaksud dengan "hak eksklusif" adalah hak yang hanya diberikan kepada Pemegang paten untuk jangka waktu tertentu guna melaksanakan sendiri secara komersial atau memberikan hak lebih lanjut untuk itu kepada orang lain. Dengan demikian, orang lain dilarang melaksanakan paten tersebut tanpa persetujuan Pemegang Paten"

\footnotetext{
${ }^{17}$ Tetapi karena menurut KPPU bahwa perpanjangan perjanjian Supply Agreement yang ditandatangani Pfizer Overseas dan PT. Dexa Medica pada tanggal 13 Juni 2007 dan berlaku surut sejak tanggal 1 April 2007 dilakukan setelah masa paten Amlodipine Besylate berakhir tanggal 3 April 2007, maka perpanjangan perjanjian Supply Agreement antara Pfizer Overseas dan PT. Dexa Medica tanggal 13 Juni 2007, tidak termasuk dalam pengecualian Pasal 50 huruf b UU No. 5 Tahun 1999.
} 
Selanjutnya, berdasarkan Pasal 1 angka 11 UU No. 13 Tahun 2016 mengartikan bahwa:

"Lisensi adalah izin yang diberikan oleh pemegang paten, baik yang bersifat eksklusif maupun non-eksklusif, kepada penerima lisensi berdasarkan perjanjian tertulis untuk menggunakan Paten yang masih dilindungi dalam jangka waktu dan syarat tertentu"

Hak kekayaan intelektual memiliki tujuan untuk mendorong terciptanya inovasi teknologi sehingga dapat mewujudkan sistem perekonomian yang maju dan sebagai akibatnya konsumen menjadi sejahtera. Hak kekayaan intelektual, khususnya Paten memberikan inventor suatu hak eksklusif untuk mengeksploitasi invensi yang dihasilkannya sehingga mendapatkan keuntungan ekonomi selama jangka waktu tertentu. Keuntungan ekonomi yang didapatkan merupakan suatu bentuk penghargaan kepada inventor atas upayanya dalam menciptakan suatu invensi dengan pengorbanan materi, waktu, pikiran yang digunakan.

Pemegang paten cenderung akan menyalahgunakan kekuatan pasar melalui beberapa cara, antara lain penolakan untuk memberikan lisensi, memberikan lisensi namun dengan persyaratan yang tidak wajar, melakukan penetapan harga yang tidak wajar atau harga yang berlebihan, menyalahgunakan posisi dominan yang dimilikinya, dan sebagainya.

Perilaku pemegang paten yang sering dijumpai adalah tindakan penetapan harga yang berlebihan. Penetapan harga yang berlebihan yang dilakukan atas dasar posisi dominan dalam pasar dapat dianggap sebagai tindakan yang hukum antimonopoli dan menciptakan persaingan usaha tidak sehat sehingga berdampak merugikan masyarakat. Penetapan harga secara berlebihan dapat diukur dengan cara memperhitungkan perbandingan biaya yang dikeluarkan dengan harga yang dibebankan terhadap produk dalam pasar. Sedangkan penetapan harga dapat dianggap wajar jika memperhitungkan faktor-faktor objektif yang berkontribusi pada biaya produksi dan manajemen.

Akan tetapi, Hak eksklusif yang diperoleh dari Paten hanyalah merupakan hak milik. Hak milik adalah suatu fondasi dalam pasar ekonomi. Hak milik atas hak kekayaan intelektual yang bersifat intangible asset (asset yang tak berwujud) pada prinsipnya adalah sama dengan hak milik atas tangible asset (asset yang berwujud) karena tidak mengizinkan orang lain untuk menggunakan asset tersebut kecuali dengan persyaratan tertentu dari pemiliknya.

Sifat hak kekayaan intelektual termasuk hak paten bersifat monopolistik. Undangundang paten akan berupaya mendorong inovasi dengan memberikan monopoli terbatas atas invensinya. Karena pemegang paten diberi wewenang secara hukum untuk mencegah orang lain dari melanggar haknya dan dengan demikian memperoleh keuntungan ekonomi, sehingga hak paten terlihat bertentangan dengan persaingan usaha. Oleh karena itu, jika hak kekayaan intelektual dipergunakan dengan cara yang baik dan benar akan melengkapi tujuan dari kebijakan hokum persaingan 
usaha dan tidak menciptakan konflik. Undang-undang anti-monopoli bertujuan untuk menumbuhkan persaingan di pasar dengan mencegah penyalahgunaan posisi dominan, yang secara alami diciptakan oleh hak paten. ${ }^{18}$

Sistem hukum Paten tidak banyak memperhitungkan tentang perilaku-perilaku yang sifatnya strategis atau "monopolistik", termasuk perusahaan dengan posisi dominan yang mengecualikan kompetitif dalam membeli paten yang mereka miliki. Sebagian besar sistem hukum paten seolah-olah menganggap bahwa pasar tidak penting dan tidak memperdulikan apakah perilaku strategis dapat memberikan manfaat atau justru memiliki potensi yang membahayakan.

Pelajaran pentingnya dari kasus Perjanjian Supply Agreement 2007 antara PT. Dexa Medica bersama dengan Pfizer Overseas Llc (d/h Pfizer Overseas Inc) atas pelaksanaan Paten zat aktif Amlodipine Besylate di atas, dan penetapan harga yang berlebihan membuktikan bahwa paten tidak dapat terhindar dari terjadinya penyalahgunaan hak eksklusif dari Posisi Dominan Pemegang Paten di dalam persaingan usaha. Akibatnya menjadi pemusatan kekuatan ekonomi oleh satu atau lebih pelaku usaha yang mengakibatkan dikuasainya produksi dan atau pemasaran atas barang dan atau jasa tertentu sehingga menimbulkan persaingan usaha tidak sehat dan dapat merugikan kepentingan umum. Sehingga berdasarkan Pasal 6 huruf c Peraturan Pemerintah Republik Indonesia Nomor 36 Tahun 2018 tentang Pencatatan Perjanjian Lisensi Kekayaan Intelektual mengatur bahwa "Perjanjian Lisensi dilarang memuat ketentuan yang dapat mengakibatkan persaingan usaha tidak sehat".

Dengan demikian, perlu dilakukan peninjauan kembali pengecualian perjanjian yang berkaitan dengan hak atas kekayaan intelektual seperti lisensi dan paten dari Pasal 50 UU No. 5 Tahun 1999. Sehingga pelaksanaan Paten dan lisensinya yang diduga mengakibatkan praktik monopoli dan/atau persaingan usaha tidak sehat dapat menjadi objek pengawasan dan putusan KPPU. Untuk kemudian, dapat ditindaklanjuti dengan penggunaan Lisensi Wajib Paten yang diberikan untuk memperbaiki praktik persaingan usaha tidak sehat dalam pelaksanaan Paten berdasarkan Pasal 31 huruf k TRIPs Agreement dan Pasal 14 Permenkumham No. 30 Tahun 2019. Di sisi lain, perlu dipertimbangkan untuk menjadikan Lisensi Wajib Paten yang diberikan untuk memperbaiki praktik persaingan usaha tidak sehat sebagai tambahan alternatif tindakan administratif KPPU dalam Pasal 47 UU No. 5 Tahun 1999.

Karena bagaimanapun, hubungan antara hukum persaingan usaha dan hak paten terlihat kontradiktif berbeda dengan kenyataannya. Sebaliknya, hukum persaingan usaha dan hak paten mendorong persaingan dinamis dengan membatasi persaingan statis. Sehingga pemegang paten memberikan keuntungan pada awal kompetisi atas pesaing mereka, dengan memungkinkan pemegang paten untuk mengeksploitasi paten selama jangka waktu tertentu. Selama periode masa paten berlaku, pemegang paten akan memiliki monopoli dan posisi dominan. Hukum persaingan usaha tidak pernah

${ }^{18}$ Mamta Rani Jha. (2018, 16 April). Loc. Cit. 
benar-benar melarang hak monopolistik. Tetapi jika hak monopolistik disalahgunakan maka akan menjadi pelanggaran undang-undang anti-monopoli. Posisi dominan yang dimiliki oleh pemegang paten tidak melanggar hukum persaingan usaha, tetapi lebih kepada penyalahgunaan posisi dominan tersebut. Singkatnya, hukum persaingan usaha dan hak paten memiliki tujuan yang sama, tetapi memiliki cara mencapainya yang berbeda. ${ }^{19}$

\section{KESIMPULAN DAN SARAN}

Berdasarkan kasus Supply Agreement 2007 antara PT. Dexa Medica bersama dengan Pfizer Overseas Llc (d/h Pfizer Overseas Inc) atas pelaksanaan Paten zat aktif Amlodipine Besylate dan Pasal 31 huruf k TRIPs Agreement yang diratifikasi dengan UU No. 7 Tahun 1994 pada Lampiran 25 serta Pasal 14 Permenkumham No. 30 Tahun 2019 perlu ditindaklanjuti dengan penggunaan Lisensi Wajib Paten yang diberikan untuk memperbaiki praktik persaingan usaha tidak sehat, maka perlu dilakukan peninjauan kembali pengecualian perjanjian yang berkaitan dengan hak atas kekayaan intelektual seperti lisensi dan paten dari Pasal 50 UU No. 5 Tahun 1999. Sehingga pelaksanaan Paten dan lisensinya yang diduga mengakibatkan praktik monopoli dan atau persaingan usaha tidak sehat dapat menjadi objek pengawasan dan putusan KPPU. Adapun untuk menjadikan Lisensi Wajib Paten yang diberikan untuk memperbaiki praktik persaingan usaha tidak sehat, sebagai tambahan alternatif tindakan administratif KPPU berdasarkan Pasal 47 UU No. 5 Tahun 1999.

\section{REFERENSI}

Agreement Establishing the World Trade Organization Nomor Annex 1C Tahun 1994 tentang Agreement on Trade-Related Aspects of Intellectual Property Rights.

Andi Fahmi Lubis \& Ningrum Natasya Sirait (Eds.). (2009). Hukum Persaingan Usaha: Antara Teks dan Konteks. Jakarta: Gesellschaft für Technische Zusammenarbeit (GTZ).

Editorial. (2018). Laporan Kinerja: Komisi Pengawas Persaingan Usaha 2017. Jakarta: Komisi Pengawas Persaingan Usaha (KPPU) RI.

Editorial. (2019, 24 April). Amlodipine Besylate. Dalam DrugBank. Diakses dari https://www.drugbank.ca/salts/DBSALT001054, pada tanggal 26 Maret 2020.

Editorial. (2019, 27 Desember). Compulsory Licensing of Pharmaceuticals and TRIPS. Dalam World Trade Organization. Diakses dari https://www.wto.org/english/ tratop_e/trips_e/public_health_faq_e.htm, pada tanggal 26 Maret.

Ida Bagus Kade Benol Permadi \& A. A Ketut Sukranatha. (2015). Konsep Rule of Reason untuk mengetahui Praktek Monopoli. Kertha Semaya: Journal Ilmu Hukum, Universitas Udayana, 3(3), hlm. 1 - 6. 
Indah Nirmalasari Parinduri. (2013). Pengaruh Pasar Modern terhadap Pasar Tradisional Ditinjau dari Perspektif Teori Hukum. DalamJendela Informasi Hukum: Bidang Perdagangan, diedit oleh Sutowibowo Setiadhy, Simon Tumanggor, \& Mu'min. Jakarta: Biro Hukum, Kementerian Perdagangan.

J. D. Jaspers. (2017). Managing Cartels: How Cartel Participants Create Stability in the Absence of Law. European Journal on Criminal Policy and Research, Springer Nature, 23, hlm. 319 - 335.

Jonaedi Efendi \& Johnny Ibrahim. (2016). Metode Penelitian Hukum: Normatif dan Empiris. Jakarta: Kencana Prenada Media Group.

Keputusan Presiden Republik Indonesia Nomor 24 Tahun 1979 tentang Pengesahan "Paris Convention for the Protection of Industrial Property" Tanggal 20 Maret 1883 sebagaimana Beberapa Kali Diubah Terakhir Tanggal 14 Juli 1967 di Stockholm, dengan Disertai Persyaratan (Reservation) terhadap Pasal 28 Ayat (1) dan Pasal 1 sampai dengan Pasal 12 Konvensi dan "Convention Establishing the World Intellectual Property Organization" yang Telah Ditandatangani di Stockholm, pada Tanggal 14 Juli 1967. Lembaran Negara Republik Indonesia Tahun 1979 Nomor 15.

Keputusan Presiden Republik Indonesia Nomor 15 Tahun 1997 tentang Perubahan Keputusan Presiden Nomor 24 Tahun 1979 tentang Pengesahan Paris Convention for the Protection of Industrial Property dan Convention Establishing the World Intellectual Property Organization.

Keputusan Presiden Republik Indonesia Nomor 75 Tahun 1999 tentang Komisi Pengawas Persaingan Usaha.

Mamta Rani Jha. (2018, 16 April). The Interplay between Patents and Anti-Competitive Practices. Dalam IAM. Diakses dari https://www.iam-media.com/law-policy/ interplay-between-patents-and-anti-competitive-practices, pada tanggal 25 Maret 2020.

Nurul Qamar, et al. (2017). Metode Penelitian Hukum (Legal Research Methods). Makassar: CV. Social Politic Genius (SIGn).

Peraturan Menteri Hukum dan Hak Asasi Manusia Republik Indonesia Nomor 30 Tahun 2019 tentang Tata Cara Pemberian Lisensi-Wajib Paten. Berita Negara Republik Indonesia Tahun 2019 Nomor 1570.

Peraturan Pemerintah Republik Indonesia Nomor 36 Tahun 2018 tentang Pencatatan Perjanjian Lisensi Kekayaan Intelektual. Lembaran Negara Republik Indonesia Tahun 2018 Nomor 115. Tambahan Lembaran Negara Republik Indonesia Nomor 6229.

Peraturan Presiden Republik Indonesia Nomor 80 Tahun 2008 tentang Perubahan Atas Keputusan Presiden Nomor 75 Tahun 1999 tentang Komisi Pengawas Persaingan Usaha.

Rachmadi Usman. (2013). Hukum Persaingan Usaha di Indonesia. Jakarta: Sinar Grafika.

Soerjono Soekanto \& Sri Mamudji. (2015). Penelitian Hukum Normatif: Suatu Tinjauan Singkat. Jakarta: PT. Raja Grafindo Persada. 
Udin Silalahi \& Isabella Cynthia Edgina. (2017). Pembuktian Perkara Kartel di Indonesia dengan Menggunakan Bukti Tidak Langsung (Indirect Evidence). Jurnal Yudisial, Komisi Yudisial Republik Indonesia, 10(3), hlm. 311 - 330. doi: http://dx.doi. org/10.29123/jy.v10i3.216

Undang-Undang Dasar Negara Republik Indonesia Tahun 1945.

Undang-Undang Republik Indonesia Nomor 7 Tahun 1994 tentang Pengesahan Agreement Establishing the World Trade Organization (Persetujuan Pembentukan Organisasi Perdagangan Dunia). Lembaran Negara Republik Indonesia Tahun 1994 Nomor 57. Tambahan Lembaran Negara Republik Indonesia Nomor 3564.

Undang-Undang Republik Indonesia Nomor 5 Tahun 1999 tentang Larangan Praktek Monopoli dan Persaingan Usaha Tidak Sehat. Lembaran Negara Republik Indonesia Tahun 1999 Nomor 33. Tambahan Lembaran Negara Republik Indonesia Nomor 3817.

Undang-Undang Republik Indonesia Nomor 13 Tahun 2016 tentang Paten. Lembaran Negara Republik Indonesia Tahun 2016 Nomor 176. Tambahan Lembaran Negara Republik Indonesia Nomor 5922. 